\title{
Mitos Vagina Ideal dalam Iklan Sabun Kewanitaan
}

\author{
Wiwid Adiyanto \\ Universitas Amikom Yogyakarta \\ Email: wiwidadiyanto@amikom.ac.id
}

Diterima : 18 Mei 2021

Disetujui : 31 Juli 2021

Diterbitkan : 20 Agustus 2021

\begin{abstract}
Abstrak
Sabun kewanitaan dipromosikan sebagai produk yang sehat dan memiliki dampak positif dalam kehidupan rumah tangga, termasuk Purbasari Manjakani Whitening. Di sisi lain, penelitian medis menunjukkan adanya potensi risiko kesehatan dari pemakaian produk pembersih vagina. Harga yang relaif terjangkau dan dampak yang disimulasikan membuat Purbasari Manjakani Whitening menempati 5 besar Top Product selama 4 tahun terakhir. Tujuan penelitian ini adalah untuk membedah mitos terkait dengan vagina dari iklan Purbasari Manjakani Whitening. Penelitian ini menggunakan pendekatan kualitatif deskriptif dengan analisis semiologi Roland Barthes. Hasil penelitian ini menunjukkan bahwa vagina ideal adalah vagina yang rapat, berwarna putih, dan wangi. Mitos ternaturalisasi sehingga membangun efek panoptik bagi perempuan untuk menjaga vaginanya dalam kategori tubuh yang patuh. Biopower bekerja melalui isu keharmonisan keluarga. Kondisi tersebut membuat perempuan terjebak dalam perjalanan keidealan tanpa akhir untuk memenuhi tuntutan vagina ideal. Konstruksi vagina ideal tidak terlepas dari relasi kuasa yang mana hubungan seksual tidak lagi merupakan kepuasan kedua belah pihak, melainkan mengalir pada lakilaki sebagai suami.
\end{abstract}

Kata Kunci: vagina, mitos, iklan, semiologi

\begin{abstract}
Feminine soap is promoted as a healthy product and has a positive impact on household life, including Purbasari Manjakani Whitening. On the other hand, medical research has shown potential health risks from using vaginal cleansing products. Relatively affordable prices and simulated impacts have made Purbasari indulge in the whitening of the top 5 main products for the past 4 years. The purpose of this study was to dissect the myths related to the vagina from the advertisement of Purbasari Manjakani Whitening. This study uses qualitative descriptive approach with semiology analysis of Roland Barthes. The results of this study indicate that the ideal vagina is one that is tight, white, and fragrant. Myths naturalized thus establishing a panoptic effect for women to keep their vaginas in the submissive body category. Biopower works through family harmony issues. This condition traps women on an endless idealistic journey to fulfill vaginal instructions. The ideal vaginal construction cannot be separated from the power relation in which sexual relations are no longer the satisfaction of both parties, flowing to men as husbands.
\end{abstract}

Keywords: vagina, myth, advertisement, semiology

\section{PENDAHULUAN}

Penayangan perempuan dalam iklan tidak bisa lepas dari representasi sosok perempuan ideal. Permasalahan tersebut setidaknya bisa dilihat pada dua kategori yaitu, representasi (1) peran dan (2) tubuh perempuan dalam media massa. Tiap bagian tubuh perempuan dari rambut sampai kaki menjadi perhatian industri untuk membangun wacana perempuan ideal. Vagina menjadi bagian tubuh perempuan yang tidak luput untuk dipersoalkan dalam industri melalui pesan iklan. Dominasi maskulin membuat vagina erat dikaitkan dengan tidakan seksual yang didominasi oleh maskulin itu sendiri (Bourdieu, 
2010, p. 25). Salah satu penggambaran perempuan dalam iklan adalah sebagai objek seksual dan pengkonsumsi barang dan jasa serta sebagai alat pembujuk (Sunarto, 2009, p. 4). Wacana tersebut membuat perempuan berlomba untuk mendapatkan pengakuan baik dari laki-laki maupun bagi sesama perempuan. Fokus kajian akademis sosial saat ini masih didominasi oleh kajian ukuran tubuh serta peran perempuan dalam media massa. Permasalahan khusus lainnya yang belum mendapatkan perhatian lebih adalah konstruksi vagina melalui tanda-tanda yang ditayangkan melalui iklan media massa.

Iklan di media televisi merupakan bagian dari bauran promosi yang melibatkan aspek berbayar untuk ruang dan waktu. Pesan yang dikonstruksikan melalui berbagai tanda dalam iklan memungkinkan untuk diterima sekelompok besar individu pada saat yang bersamaan (Belch \& Michael E. Belch, 2017, p. 16). Lebih jauh lagi iklan merupakan bagian bentuk ekspresi bahasa simbolik dalam kebudayaan manusia. Perkembangan makna dominasi simbolik oleh wacana iklan telah mengganti realitas dengan kesadaran palsu (Kasiyan, 2008, pp. 143-144). Hal itu membuat konsep ideal atas sesuatu tidak terlepas dari iklan sebagai instrumen penyebaran wacana.

Keidealan setiap bagian tubuh bagi perempuan memungkinkan ketidakpuasan terhadap tubuh sendiri, termasuk bagian vagina. Lebih jauh lagi, terdapat histerisasi yang tertuju pada perempuan terkait dengan vagina ideal. Aroma vagina, bentuk genitalia, kekencangan vagina, dan tampak bersihnya vagina memicu perempuan untuk selalu melakukan koreksi diri dan berkecenderungan menjadi tidak percaya diri terkait vaginanya (CNN Indonesia, 2019). Kondisi setelah melahirkan juga cenderung dikhawatirkan perempuan karena membuat vagina terkesan lebih longgar (Sukmasari, 2017). Vagina yang relatif tidak kencang sampai bisa menghilangkan kepercayaan diri saat berhubungan seksual (Kania, 2019). Vagina yang kencang atau rapat merupakan kebanggaan karena dianggap lebih memuaskan suami dalam berhubungan seksual. Vagina merupakan salah satu faktor untuk mendapatkan rasa sayang pasangan. Sebaliknya, vagina yang kendur merupakan salah satu keluhan suami yang ditujukan pada istri (Virdhani, 2019).

Purbasari Manjakani Whitening merupakan salah satu produk dari merek Purbasari yang diproduksi oleh PT. Gloria Origita Cosmetics. Purbasari Manjakani Whitening selalu masuk dalam urutan 5 besar pada survei Top Brand Index selama tahun 2017 sampai 2020 dalam kategori sabun pembersih daerah kewanitaan (Top Brand Awards, 2020). Produk tersebut mulai tayang di iklan televisi pada tahun 2016 dan sampai saat ini produknya masih ramai di pasaran. Hal itu menunjukan bahwa produk tersebut berhasil diingat publik sampai saat ini dan menjadi referensi dalam penggunaan sabun kewanitaan. Iklan Purbasari Manjakani Whitening menampilkan 3 perempuan dan 3 laki-laki yang secara bergantian memberikan komentar terkait efek yang didapat setelah perempuan menggunakan produk tersebut. Sebagai media massa, iklan Purbasari Manjakani juga dipercaya memiliki mitos tertentu terkait produk yang ia tawarkan. Secara sederhana, iklan di media massa bukan sekedar instrumen pemberi informasi terkait fungsi suatu produk secara esensial. Sobur (dalam Purnamasari, 2020, p. 31) menyatakan bahwa film ataupun iklan di media massa bisa mempengaruhi penonton terkait ideologi dari visualisasi dengan cakupan sosial yang luas.

Produk pembersih vagina dipromosikan sebagai produk yang sehat dan memiliki khasiat keharmonisan keluarga. Harga yang relatif terjangkau dan dampak yang 
disimulasikan membuat Purbasari Manjakani Whitening masih bertahan di pasaran. Hal tersebut tidak diiringi oleh informasi yang cukup mengenai penggunaan sabun kewanitaan dalam pesan yang disampaikan melalui iklan media massa. Pada kenyataannya, sabun kewanitaan, termasuk Purbasari Manjakani Whitening tidak hanya memiliki kegunaan yang positif namun juga mempunyai efek samping negatif. Riset yang lakukan Ana C. Pontes, dkk (dalam Primastika, 2018) menyatakan bahwa penggunaan zat pembersih vagina memiliki pengaruh pada keseimbangan mikroorganisme di vagina. Ketidak seimbangan tersebut dapat menyebabkan peradangan sampai dengan infeksi. Hal itu disebabkan karena pertumbuhan mikroorganisme yang berlebih. Portal majalah kesehatan WebMD (dalam Dewi, 2016) melansir bahwa penggunaan sabun kewanitaan bisa berdampak pada masalah komplikasi kehamilan serta $73 \%$ lebih tinggi beresiko mengalami infeksi rahim.

Komunikasi tidak terlepas dari sistem tanda yang paling fundamental yaitu bahasa, termasuk pada iklan. Tanda-tanda itu dikomunikasikan berdasarkan relasi-relasi (Sobur, 2016, p. 13). Hal itu menempatkan bahasa bukan hanya sebagai sarana komunikasi, namun juga sebagai medium kekuasaan, termasuk kekuasaan simbolis (Bourdieu, 2020, p. 16). Manipulasi iklan hadir untuk membangun citra sebenarnya sehingga tampak seperti hal yang sebenarnya. Manipulasi tersebut menyusup pada celah-celah antara nilai, gagasan, dan opini dan mengaburkannya sehingga sulit dibedakan (Haryatmoko, 2007, p. 69). Lebih jauh lagi, Richard Lippke (Phillips, 1997, p. 16) mempersoalkan etika iklan pada tataran pengacauan otonomi seseorang. Lippke menuturkan bahwa banyak individu yang sanggup menentang konten eksplisit dari iklan, tetapi tidak dengan konten implisitnya. Termasuk pada iklan Purbasari Manjakani Whitening, mitos dibangun melalui simbol-simbol yang keluar dari fungsi utama untuk suatu produk perawatan vagina.

Vagina tidak hanya memiliki makna materil, namun juga memiliki makna simbolik (Braun \& Sue Wilkinson, 2001, p. 17). Makna simbolik tersebut erat kaitannya dengan nilai sosial dan budaya yang berlaku di suatu era ataupun wilayah. Barthes (dalam Sobur, 2016, p. 68) menyatakan bahwa tanda-tanda denotatif dalam budaya populer menyiratkan konotasi yang pada dasarnya adalah mitos. Mitos dibangun oleh tanda dan membentuk kepercayaan masyarakat secara lebih luas. Dengan kata lain, budaya populer merupakan tempat pertarungan simbol yang penuh dengan mitos.

Seperti bagian tubuh lainnya, vagina juga tidak luput dari pendisiplinan oleh norma yang dianggap ideal atau nilai kebenaran dari suatu wacana. Pendisiplinan tersebut digambarkan oleh Michel Foucault melalui konsep Biopower. Foucault menjelaskan bahwa pendisiplinan bekerja melalui fungsi penindasan yang mendiskualifikasi ataupun menyingkirkan tubuh yang tidak patuh, termasuk regulasi pada vagina. Biopower juga erat kaitannya dengan kapitalisme. Kontrol tubuh merupakan mesin produksi yang membangun ideologi masyarakat konsumsi (Foucault dalam Afiati, 2019, p. 7).

Braun dan Wilkinson (2001) meneliti representasi vagina terkait dengan sosial budaya di negara barat. Braun mengidentifikasi dan menggambarkan secara umum 7 hal representasi negatif dari vagina terkait dengan sosio kultural: (1) vagina lebih inferior dari pada penis, (2) vagina sebenarnya tidak ada dan hanya sebutan untuk wadah penis, (3) vagina tidak memadai secara seksual, (4) vagina sebagai hal yang menjijikan, (5) vagina merupakan sesuatu yang rentan, (6) vagina merupakan sesuatu yang disalahgunakan, dan (7) 
vagina berbahaya. Pada tahun yang sama, Braun dan Kitzinger (2001) dalam penelitiannya menyatakan bahwa secara sosio kultural negara barat, ukuran vagina yang diinginkan perempuan adalah vagina yang cenderung rapat. Vagina yang tidak diinginkan perempuan adalah vagina yang longgar. Perempuan yang memiliki vagina longgar diposisikan seperti perempuan yang tidak memilih-milih dalam berhubungan seksual. Vagina yang longgar juga kerap menjadi kata umpatan. Perempuan yang memiliki vagina rapat atau merekonstruksi kerapatan vaginanya melalui operasi bedah juga mengalami kecemasan karena dianggap terlalu ketat. Penelitian Braun membuktikan bahwa pada saat itu perempuan mengesampingkan kenikmatan seksual dan kurang akrab dengan fungsi vagina yang ada pada perempuan tersebut.

Studi lain yang telah dilakukan oleh Sara Rodrigues (2012) yang membahas tentang Biopolitik dari bedah vagina. Penelitiannya menunjukan bahwa, vagina diregulasi menuju kategori optimal melalui operasi untuk kepentingan penetrasi. Hal itu menunjukan bahwa biopower tersebut mengukur nilai perempuan tidak hanya dalam hal potensi reproduksi dan persalinan mereka (Foucault dalam Rodrigues, 2012) tetapi sekarang juga oleh kemampuan mereka untuk menyediakan dan memelihara wadah yang ketat untuk penetrasi penis. Kondisi tersebut membuat beban biopolitik tambahan. Hiper-visibilitas vulva yang dipertahankan oleh budaya seperti pornografi dan waxing di barat, akhirnya memungkinkan terbangunnya estetika atau fantasi "kebersihan" feminin ideal. Operasi bedah vagina dengan tujuan estetika yang digiring oleh biopower dianggap sebagai investasi.

Ketiga penelitian di atas memiliki kemiripan dengan yang terjadi di Indonesia. Adiyanto (2018) telah melakukan penelitian yang berjudul "Narasi Komunikasi Pengakuan Diri Perempuan Kepada Pasangannya Mengenai Ketidak Perawanan". Studi tersebut menggunakan metode analisis narasi Tzvetan Todorov yang telah dikembangkan oleh Nick Lacey dan Gillespie. Poin penekanan dalam studi tersebut adalah narasi pengakuan ketidak perawanan perempuan kepada pasangannya ketika hendak menlanjutkan ke jenjang pernikahan. Studi tersebut menjelaskan relasi kuasa mengalir pada orang yang diberi informasi yaitu laki-laki. Perempuan sebagai pihak yang memberikan informasi menjadi lebih inferior. Keperawanan yang berhubungan dengan vagina dianggap sebagai ukuran baik atau buruknya perempuan, sementara laki-laki tidak dituntut dengan porsi norma yang sama secara sosio kultural.

Rosida dan Sari (2017) meneliti terkait representasi iklan komersial media massa di Indonesia yaitu make-up Wardah dan Resik-V Manjakani. Studi tersebut menggunakan konsep representasi dan identitas dari Stuart Hall. Rosida dan Sari memaparkan bahwa kerudung dalam iklan wardah merepresentasikan ke-salihah-an dan moderenitas berkerudung sebagai identitas muslimah, sedangkan iklan Resik-V cenderung merepresentasikan perempuan ideal dari sudut pandang laki-laki. Lebih jauh lagi, Simeon (2018) telah melakukan studi pemaknaan khalayak dari konstruksi vagina di iklan televisi Feminine Hygine Resik-V. Studi yang Simeon lakukan menggunakan metode analisis resepsi Stuart Hall dan pendekatan teori Kekerasan Simbolik Pierre Bordieu. Simeon menyatakan bahwa adanya keragamaan posisi pemaknaan dari khalayak yaitu, khalayak pembaca dominan, khalayak pembaca yang merujuk pada negosiasi, dan khalayak pembaca oposisi. 
Studi terkait vagina dan produk pembersih vagina juga dilakukan oleh Jenkins dan O’Doherty (2020) yang fokus pada keterkaitan penggunaan pembersih vagina dengan nilai sosial tentang vagina. Studi tersebut menggunakan analisis kode tematik induktif dari Braun dan Clarke. Jenkins membagi kondisi vagina menjadi 3 kategori yaitu, vagina yang sehat, vagina yang tampak bersih, dan vagina yang tampak kotor. Temuan dari studinya menunjukan bahwa pengguna pembersih vagina memprioritaskan vagina yang tampak bersih dan vagina yang sehat. Namun apabila harus memilih salah satu, para informannya lebih memlih vagina yang tampak bersih. Prioritas vagina bersih yang ideal ini terkait dengan tekanan masyarakat yang menuntut capaian standar kebersihan vagina yang tidak realistis.

Di sisi lain, Risman dan Karim (2020) meneliti terkait citra perempuan dalam iklan sabun Shinzui. Penelitiannya menyatakan bahwa sifat-sifat feminin disematkan pada perempuan dalam iklan dan penonjolan fisik atau biologisnya merupakan strategi yang ditujukan untuk menarik konsumen. Perempuan memiliki daya tarik biologis atau fisik, dan karakter seperti perilaku lemah lembut, gemulai dan anggun. Dengan kata lain, membangun wacana ideal terkait warna kulit, perilaku, dan sifat perempuan dalam iklan sabun Shinzui pada iklan televisi dianggap sebagai strategi pemasaran yang efektif.

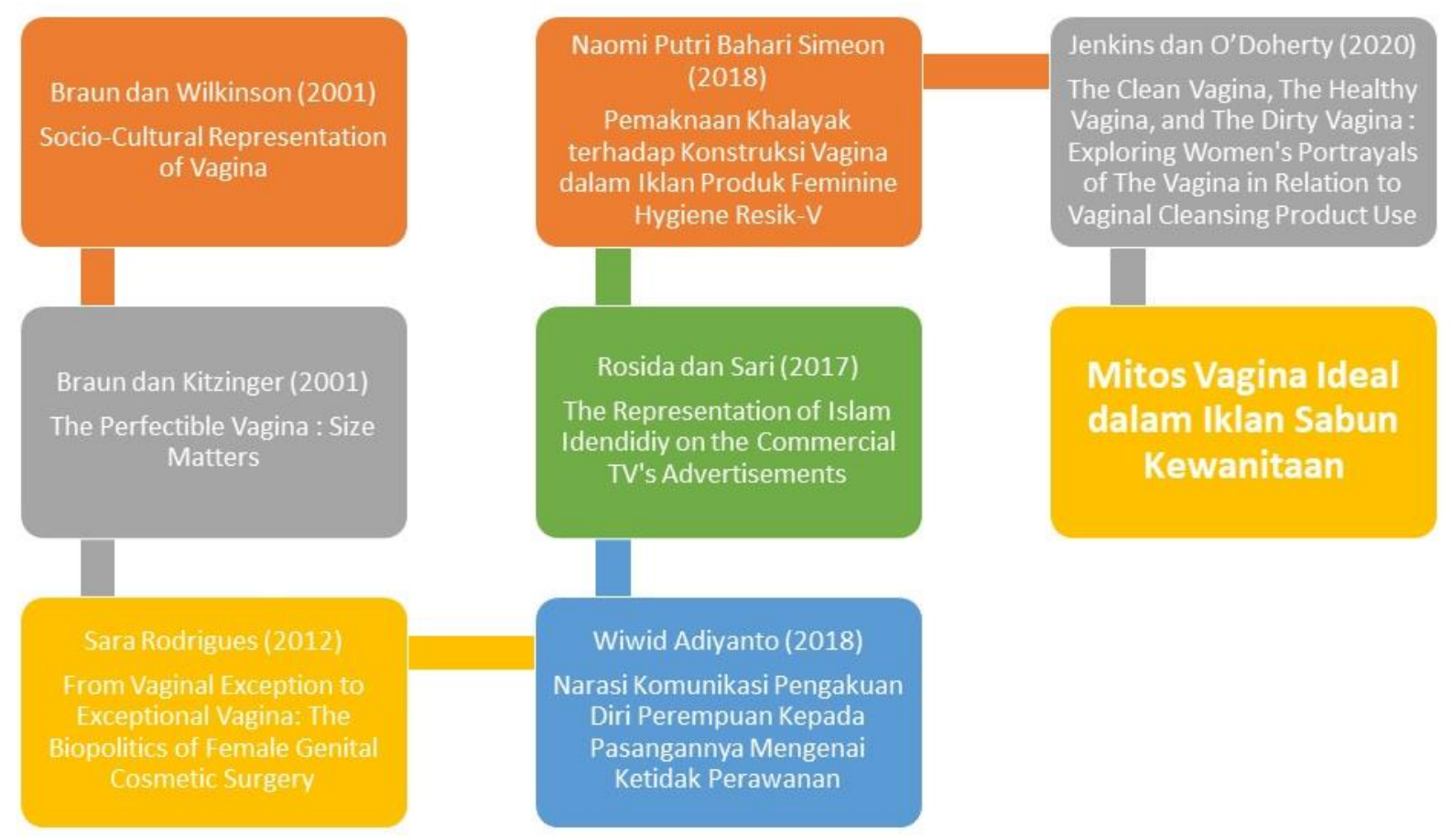

Gambar 1. Peta jalan penelitian

Penelitian ini berusaha mengisi celah dari penelitian yang disebutkan sebelumnya. Peneliti ini menawarkan kebaruan dengan fokus melihat konstruksi mitos yang didapat dari tanda-tanda dalam teks iklan Purbasari Manjakani Whitening. Penelitian ini juga merujuk pada konsep Biopower Foucault untuk melihat bagaimana Biopower bekerja dari dampak wacana atau mitos yang diperkuat oleh tayangan iklan komersial di media massa. Penelitian ini berusaha menjawab bagaimana konstruksi pesan yang merujuk pada mitos dari iklan Purbasari Manjakani Whitening? Setidaknya ada dua tujuan dari studi ini: (1) Mengetahui mitos terkait dengan vagina dari iklan Purbasari Manjakani Whitening, dan (2) Memberikan 
saran komunikasi periklanan berbasis broadcast dalam pemilihan ide terkait sabun kewanitaan.

\section{METODOLOGI PENELITIAN}

Penelitian ini menggunakan metode semiologi atau analisis mitologi dari Roland Barthes. Paradigma dalam penelitian ini mengacu pada paradigma kritis. Secara ontologis paradigma kritis memiliki sifat realisme historis yang berarti suatu realitas bisa berubah oleh serangkaian faktor sosial, politik, budaya, etnik, ekonomi, dan gender menjadi struktur yang dianggap alamiah dan abadi. Sedangkan secara epistimologi memiliki sifat transaksional dan subjektivis. Secara metodologi, paradigma kritis bersifat dialogis dan dialektis (Denzin \& Lincoln, 2009, p. 136). Barthes (dalam Sobur, 2016, p. 71) memahami ideologi sebagai kesadaran palsu yang akhirnya mengarahkan individu-individu ke dalam dunia imajiner dan ideal melalui tanda-tanda. Hal itu terjadi meski realitas hidup yang sebenarnya tidak demikian. Hal tersebut merujuk pada bagaimana iklan media massa, dalam hal ini Purbasari Manjakani Whitening menghadirkan mitos tentang vagina melalui tanda-tanda dalam tayangan iklannya.

Semiotika merupakan ilmu dari studi komunikasi dengan fokus intepretasi tanda yang beroperasi dalam suatu ranah (Simpson dan Weiner dalam Radford, 2005, p. 136). Semiologi merupakan istilah yang digunakan Barthes dengan rujukan yang sama, yaitu studi wicara yang merupakan satu bagian dari ilmu tanda (Barthes, 2018, p. 155). Analisis semiologi Barthes melihat mitos sebagai hal yang dihasilkan dari signifikansi tingkat kedua atau semiologi tingkat kedua. Pada tingkat pertama yang merupakan denotasi, penanda dan petanda menghasilkan tanda. Pada tingkat kedua yaitu konotasi, tanda dari signifikansi pertama itu merupakan penanda pada tingkat kedua yang memiliki petanda sehingga didapati tanda tingkat kedua atau yang disebut dengan mitos. Tanda tingkat pertama adalah denotasi dan tanda tingkat kedua adalah konotasi (Barthes, 2018, p. 162). Dengan kata lain, tanda merupakan gabungan penanda dan petanda, penanda adalah mediator atau citra akustik, suara, kata-kata atau pun bentuk materi, sedangkan petanda adalah representasi metal dari penanda (Barthes, 2017). Wilayah konotasi akan ditandai dengan huruf kapital.

\begin{tabular}{|l|l|}
\hline $\begin{array}{l}\text { 1. Penanda } \\
\text { 2. Petanda }\end{array}$ \\
$\begin{array}{l}\text { 3. Tanda } \\
\text { I. PENANDA II. PETANDA }\end{array}$ \\
\hline \multicolumn{3}{c}{ III. TANDA / MITOS } \\
\hline
\end{tabular}

Gambar 2. Model analisis Semiologi Roland Barthes (2007, p. 303)

Studi ini menganalisis teks visual dan teks audio (kata-kata yang diucapkan pemeran dalam iklan tersebut). Iklan Purbasari Manjakani Whitening terdiri dari 8 scene, 3 scene pertama diisi oleh pernyataan perempuan lalu 1 scene penutup oleh aktor perempuan berupa pengulangan kata dari pernyataan sebelumnya, dan 3 scene penyataan laki-laki lalu 1 scene penutup oleh pernyataan aktor laki-laki yang juga pengulangan dari scene sebelumnya. Penelitian ini fokus pada analisis pernyataan perempuan dan laki-laki dalam iklan ini yang keseluruhannya adalah 6 scene. Pada semiologi tingkat pertama, iklan dianalisis penanda dan 
petanda yang ada dari teks. Tanda yang didapatkan menjadi penanda tingkat kedua dan dikaitkan dengan petanda tingkat kedua sehingga konstruksi mitos iklan tersebut bisa didapat. Data primer dari studi ini adalah iklan televisi Purbasari Manjakani Whitening, sedangkan sumber data sekunder didapatkan dari dari artikel jurnal, buku, dan dokumen yang relevan dengan penelitian ini.

\section{HASIL DAN PEMBAHASAN}

Iklan Purbasari Manjakani Whitening berdurasi 30 detik yang terdiri dari 2 segmen. Pertama, komentar 3 perempuan yang mengunakan produk tersebut, dan kedua, komentar laki-laki terkait istrinya yang menggunakan produk Purbasari Manjakani Whitening. Setiap segmen ditutup dengan suatu kesimpulan yang disampaikan aktor pertama dan disandingkan dengan produk Purbasari Manjakani Whitening dalam satu frame. Iklan ini terdiri dari 3 mitos vagina ideal secara terpisah namun tidak terlepas dari 1 mitos utama. Secara lebih rinci, peneliti akan menganalisis 6 scene yang diwakilkan secara ilustratif dalam artikel ini melalui 7 potongan gambar video iklan produk tersebut.

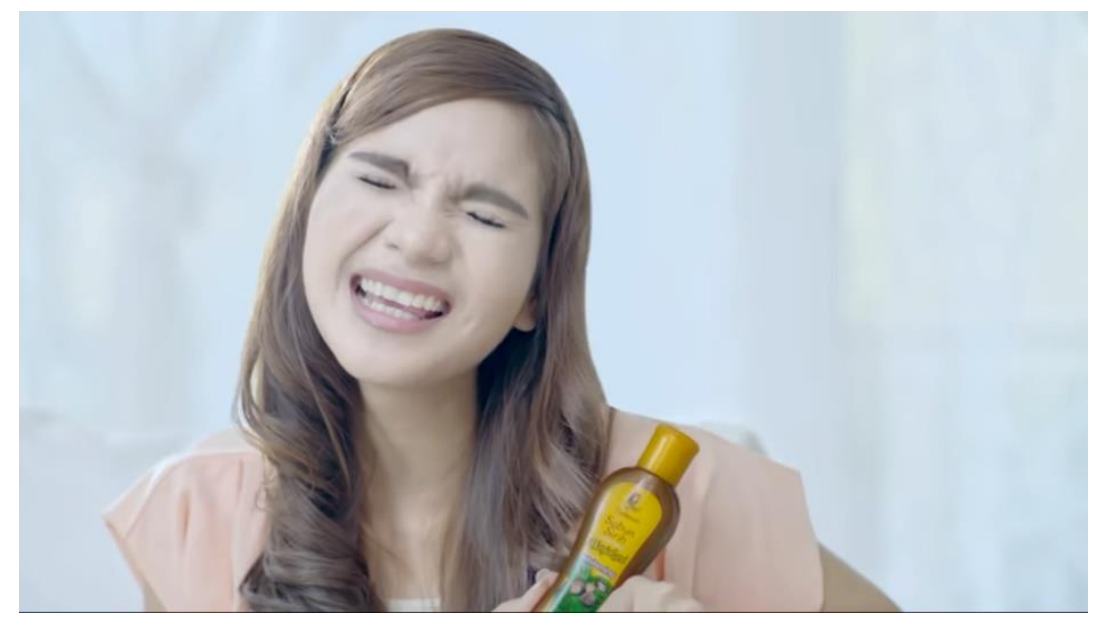

Gambar 3. Komentar perempuan pertama

Tabel 1. Analisis mitos Gambar 3

\section{Penanda}

Gambar seorang perempuan berambut panjang yang memegang Purbasari Manjakani Whitening dengan penanda suara "sejak pakai Purbasari Manjakani Whitening suami ku makin manja" dengan penekanan pada kata makin manja

\section{Petanda}

Kedipan mata dengan penekanan makin manja merujuk pada kerapatan vagina dan kepuasan hubungan seksual. Istri yang puas akan produk Purbasari Manjakani Whitening karena membuatnya dimanja suami.

3. Tanda / I. PENANDA: Seorang istri yang dimanja suami karena memiliki vagina rapat.

II. PETANDA: Vagina istri yang rapat membuat suami puas dalam hubungan seksual dan sering mengajak berhubungan seksual.

III. MITOS : Vagina yang ideal adalah vagina yang rapat 
Gambar 3 diambil dari scene pertama dalam iklan Purbasari Manjakani Whitening. Penanda denotatif memperlihatkan seorang perempuan yang berambut panjang memegang Purbasari Manjakani Whitening sambil memejamkan mata dengan penekanan dan mengucapkan "sejak pakai Purbasari Manjakani Whitening suami ku makin manja". Petanda denotatif, perempuan tersebut merupakan seorang istri, pejaman mata saat mengucapkan kata "makin" menunjukan kegemasan. Selain itu pejaman mata tersebut mengasosiasikan pada kerapatan vagina istri yang berdampak pada kesenangan suami dan pemanjaan dari suami. Dalam tahap konotatif, vagina yang rapat itu membuat suami puas dalam hubungan seksual bersama istrinya, dan kata manja menunjukan ketergantungan suami atau sering mengajak berhubungan seksual. Ketergantungan itu juga bisa dimaknai tidak selingkuh atau berhubungan badan dengan perempuan lain. Kerapatan vagina itu juga berasosiasi pada cerminan nilai budaya yaitu keperawanan. Beauvoir (2016, p. 218) memandang bahwa nilai dominan melihat keperawanan perempuan sebagai aspek yang menggelisahkan sekaligus mempesona sebagai misteri feminin pada perempuan bagi lakilaki. Tanda konotatif merujuk pada vagina istri yang ideal adalah vagina yang rapat.

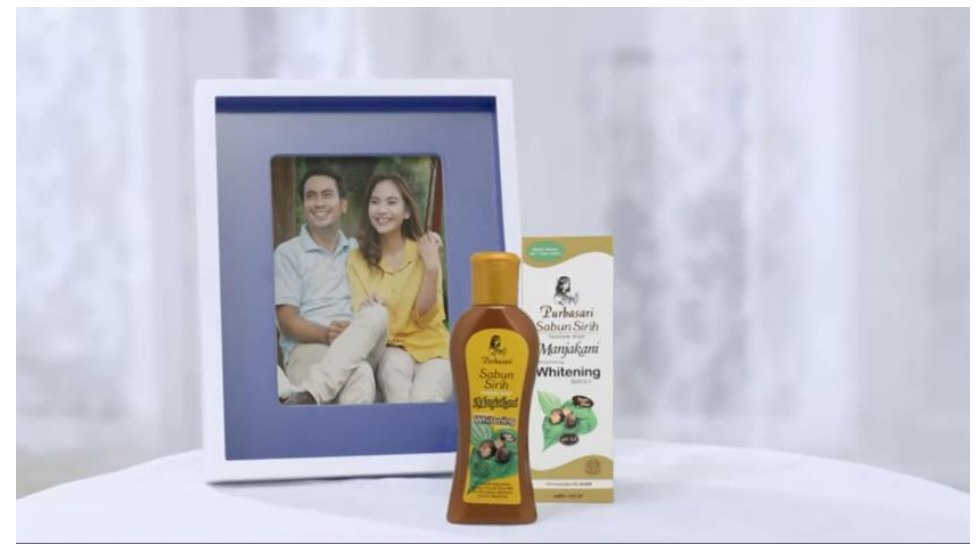

Gambar 4. Foto suami istri

Tabel 2. Analisis mitos foto suami istri Gambar 4.

\section{Penanda}

Gambar foto perempuan dan laki-laki dalam 1 frame foto dan Purbasari Manjakani Whitening di depannya. Latar putih, perempuan menggunakan baju kuning, dan laki-laki menggunakan baju biru muda.

\section{Petanda}

Foto suami istri yang harmonis. Keluarga yang mengandalkan Purbasari Manjakani Whitening untuk perawatan vagina istri. Istri yang ceria dan suami yang menenangkan.

3. Tanda / I. PENANDA: Purbasari Manjakani Whitening membentuk keluarga menjadi harmonis

II. PETANDA: Purbasari Manjakani Whitening membuat hubungan seksual menjadi lebih memuaskan

III. MITOS : Keluarga yang harmonis adalah keluarga yang menggunakan Purbasari Manjakani Whitening untuk perawatan vagina sang istri 
Masih berada di scene pertama, terdapat penanda berupa shot foto laki-laki berbaju biru muda dan perempuan berbaju kuning yang dibingkai, di depannya ada kotak dan botol Purbasari Manjakani Whitening. Petandanya, kuning memiliki konsep kegembiraan dan warna biru merujuk pada maskulin dan kesetiaan (Monica \& Luzar, 2011, pp. 1089-1090). Foto perempuan dan laki-laki yang duduk berjejer dan berada dalam satu bingkai merujuk pada kondisi suami istri yang harmonis. Dari penanda dan petanda tersebut, Purbasari Manjakani Whitening membuat relasi suami istri menjadi harmonis. Namun pada tingkat konotasi, keharmonisan itu merujuk pada kepuasan hubungan seksual yang melihat vagina istri sebagai bentuk penentu keharmonisan. Mitos dari shot itu adalah, keluarga yang harmonis mengacu pada istri yang menggunakan Purbasari Manjakani Whitening.

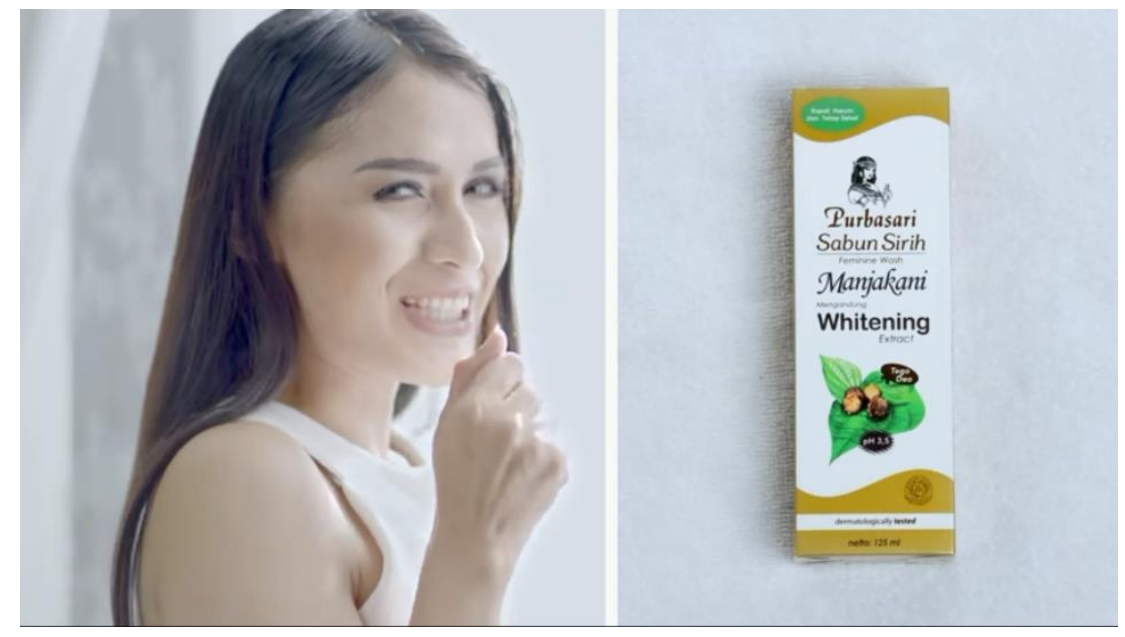

Gambar 5. Komentar perempuan kedua

Tabel 3. Analisis mitos Gambar 5

\section{Penanda}

Gambar perempuan berambut panjang,

mengenakan baju tanpa lengan berwarna putih

sambil mengepalkan jari tangan secara bertahap.

Di sampingnya adalah kemasan Purbasari

Manjakani Whitening.

Penanda suara "putihnya suami ku suka"

\section{Petanda}

Gerakan mengepalkan tangan dengan kuat secara bertahap dengan penekanan setelahnya menunjukan kerapatan dan vagina yang mengigit. Kulit sekitar vagina yang putih setelah menggunakan Purbasari Manjakani Whitening.

3. Tanda / I. PENANDA: Seorang istri yang disukai suami karena memiliki kulit disekitar vagina yang putih dan vagina yang rapat karena menggunakan Purbasari Manjakani Whitening

II. PETANDA: Kulit sekitar vagina yang putih dan vagina yang rapat membuat hubungan seksual suami jadi lebih memuaskan. Putih mewakilkan kebersihan dan kemurnian. Kemurnian seperti perawan.

III. MITOS : Warna kulit ideal di sekitar vagina adalah kulit yang putih dan Vagina yang ideal adalah rapat.

Penanda yang terlihat dari scene kedua adalah perempuan baju putih tanpa lengan dan berambut panjang sambil berkata "putihnya suami ku suka". Petandanya, pengepalan tangan secara bertahap dengan penekanan di kata "suamiku" merujuk pada kerapatan vagina 
atau vagina yang "menggigit" atau kesat. Kata putih merujuk pada kulit disekitar vagina. Dalam makna konotasi, putih mewakilkan kemurnian (Monica \& Luzar, 2011, p. 1092) yang merujuk pada keperawanan sebagai konsep yang mempesona yang dilekatkan pada perempuan muda. Alice Walker melihat bahwa warna kulit seorang individu mempengaruhi sikap individu lainnya kepada orang tersebut. Hal itu masih terkait dengan supremasi kulit putih di barat (dalam Tharps, 2016). Mitos dari scene ini adalah istri yang ideal adalah istri yang memiliki vagina yang rapat dan memiliki kulit yang putih disekitar vagina.

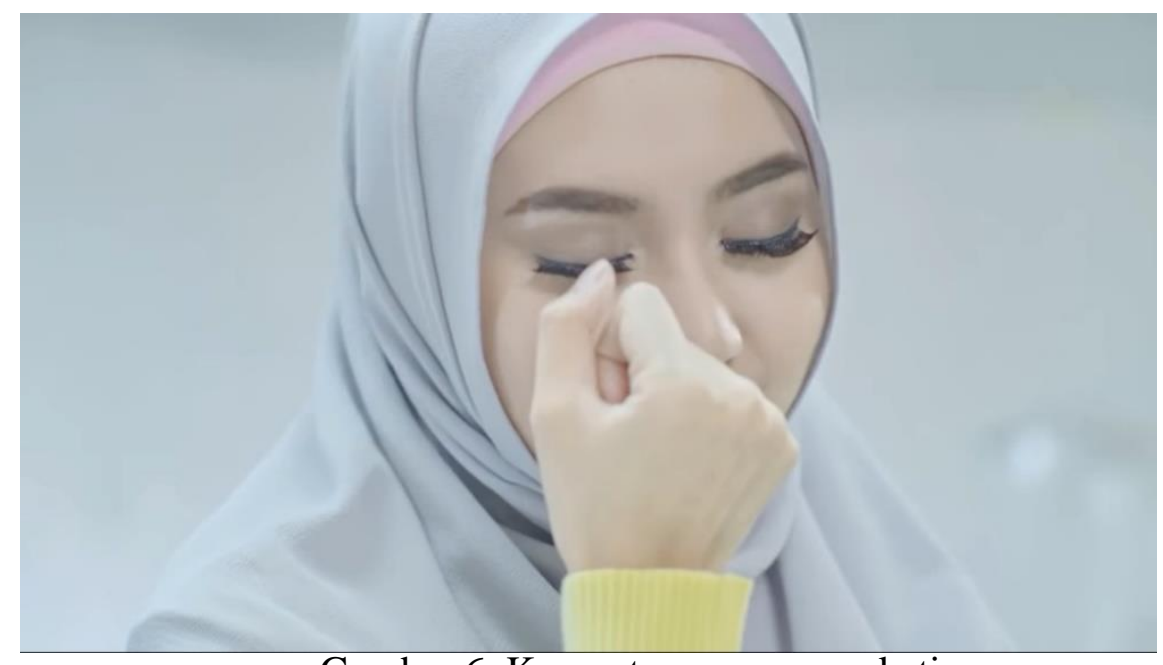

Gambar 6. Komentar perempuan ketiga

Tabel 4. Analisis Gambar 6

\begin{tabular}{|l|l|}
\hline & 2. Petanda \\
1. Penanda & Seorang muslimah yang juga seorang istri. \\
Perempuan mengenakan hijab sambil & Gerakan jari mengepal perlahan diasosiasikan \\
mngepalkan tangannya secara bertahap dan & dengan vagina yang rapat, di dekatkan \\
mendekatkan kehidung. & kehidung yang berhubungan dengan indra \\
Penanda suara "wanginya bikin kangen" & penciuman yaitu aroma. Wangi vagina yang \\
& membuat pasangan kangen. \\
\hline
\end{tabular}

3. Tanda / I. PENANDA: Seorang muslimah sebagai istri yang dirindukan pasangannya karena memiliki vagina rapat dan wangi karena Purbasari Manjakani Whitening

II. PETANDA: Purbasari Manjakani Whitening membuat vagina selalu wangi walaupun selalu tertutup. Kepuasan hubungan seksual suami berhubungan dengan aroma vagina istri yang wangi dan kerapatan vagina.

III. MITOS : Vagina istri yang ideal adalah vagina yang rapat dan wangi

Scene ketiga memperlihatkan perempuan yang mengenakan hijab. Hijab diasosiasikan dengan perempuan pemeluk agama Islam yang taat atau disebut dengan muslimah dan perempan itu merujuk pada perannya sebagai seorang istri. Sama seperti scene lainnya, gerakan mengepal jadi menunjukan kerapatan vagina. Setelah jari-jari merapat, lalu didekatkan pada hidung menunjukan aroma ideal dari vagina istri, yaitu vagina yang wangi. Pada tingkat konotasi, tuntutan itupun menjadi berat mengingat vagina merupakan bagian tubuh yang cenderung ditutupi dalam waktu yang cukup lama dalam keseharian. Mitos yang ditampilkan adalah, istri yang ideal adalah istri yang memiliki vagina rapat dan beraroma wangi. 


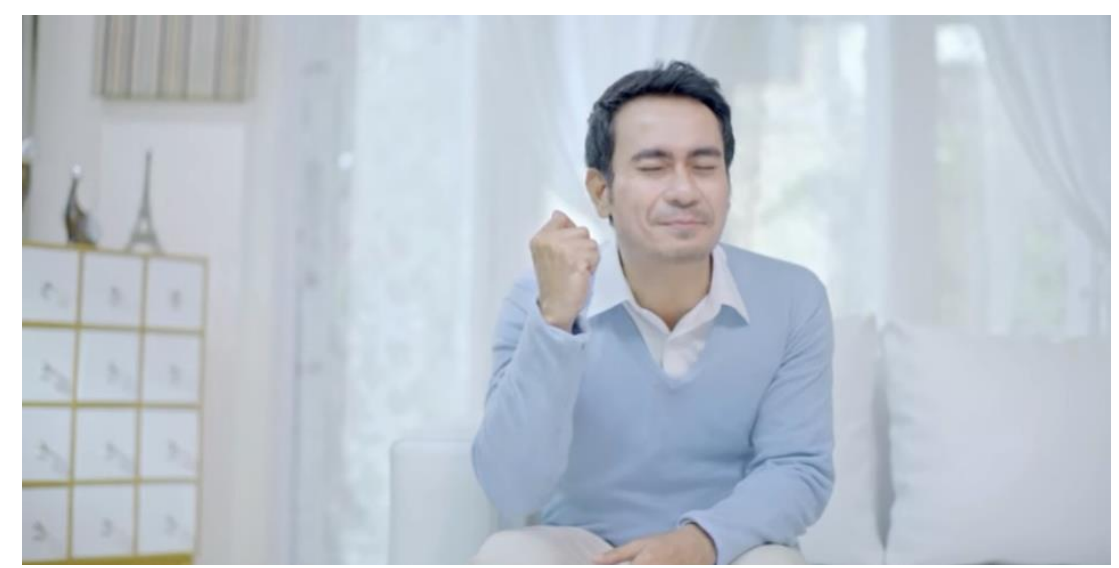

Gambar 7. Komentar laki-laki pertama

Tabel 5. Analisis Gambar 7

1. Penanda
Gambar laki-laki mengepal jari tangannya
dengan kuat dan bertahap. Mengenakan kemeja,
sweeter, dan celana panjang.
Penanda suara "Sejak pakai Purbasari Manjakani
Whitening, istri ku makin manja"

\section{Petanda}

Seorang suami pekerja kantor (pakaian semi formal). Gerakan mengepal jari diasosiasikan dengan kerapatan vagina sang istri.

3. Tanda / I. PENANDA: Seorang suami yang istrinya semakin manja sejak vagina istrinya rapat karena Purbasari Manjakani Whitening

II. PETANDA: Kepuasan seksual suami didasarkan pada vagina sang istri yang rapat.

III. MITOS : Istri yang ideal bagi suami adalah istri yang memiliki vagina yang rapat.

Scene ini menunjukan laki-laki sebagai penanda yang merujuk pada suami sebagai petanda. Labih jauh lagi, laki-laki ini merujuk pada suami dari perempuan pertama yang tampil dalam iklan ini. Gerakan menggengam yang ditekankan pada kata "makin" menegaskan kembali vagina dari istri yang rapat atau "mengigit". Dalam scene ini juga nenunjukan shot bingkai foto persis seperti yang tampil di awal. Hal itupun menegaskan kepuasan suami berdampak pada keharmonisan keluarga. Pada tingkat konotasi, kepuasan seksual bagi suami dari istri adalah ketika istri memiliki kondisi vagina yang rapat.

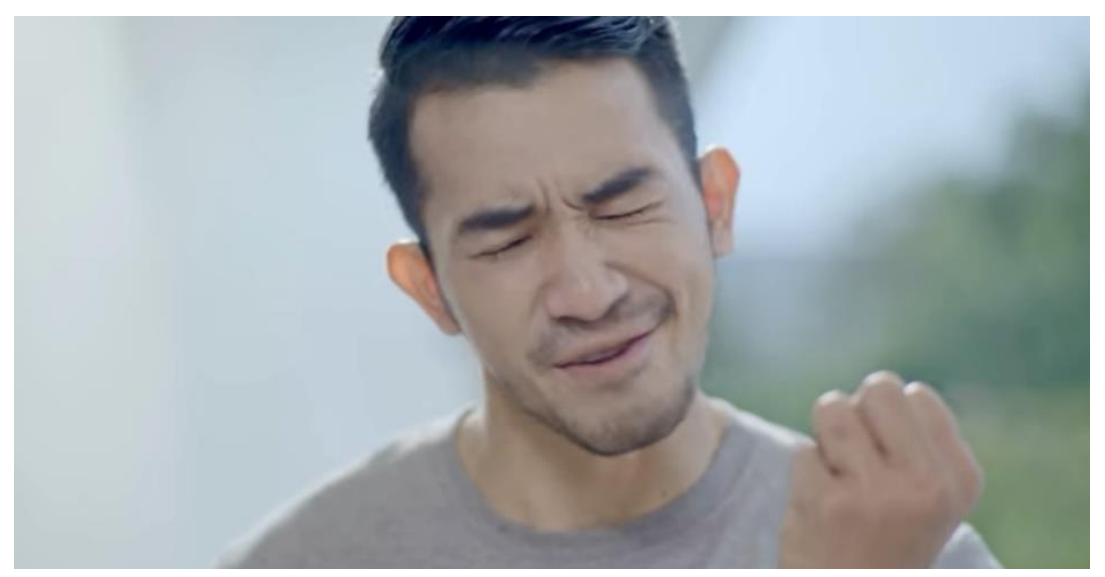

Gambar 8. Komentar laki-laki kedua 
Tabel 6. Analisis gambar 8

\begin{tabular}{|c|c|}
\hline $\begin{array}{l}\text { 1. Penanda } \\
\text { Gambar laki-laki mengepal jari dengan kuat dan } \\
\text { bertahap sambil memejamkan mata. } \\
\text { Penanda suara "aku suka putihnya" }\end{array}$ & $\begin{array}{l}\text { 2. Petanda } \\
\text { Laki-laki merujuk pada seorang suami. } \\
\text { Gerakan jari diasosiasikan dengan kerapatan } \\
\text { vagina dan kata putih juga diasosiasikan } \\
\text { dengan warna vagina istri. }\end{array}$ \\
\hline \multicolumn{2}{|c|}{$\begin{array}{l}\text { 3. Tanda / I. PENANDA: Seorang suami yang suka vagina istrinya karena rapat dan berkulit } \\
\text { putih. }\end{array}$} \\
\hline \multicolumn{2}{|c|}{$\begin{array}{l}\text { II. PETANDA: Kepuasan seksual suami didasarkan pada vagina yang rapat dan warna vagina } \\
\text { yang putih dari sang istri. Putih dan rapat diasosiasikan seperti perawan yang murni dan belum }\end{array}$} \\
\hline
\end{tabular}

Scene ini menampilkan laki-laki yang merujuk pada suami dari perempuan dalam scene kedua. Laki-laki ini juga menegaskan melalui gerakan tangannya yang mengepal tentang vagina yang rapat. Kulit yang putih, termasuk kulit di sekitar vagina dari istri merupakan hal yang disukai suami. Dalam tingkat konotasi, scene ini menegaskan kembali melalui ucapan laki-laki yang mengasosiasikan putih sebagai kemurnian yang harus diperlakukan secara istimewa dibanding warna lainnya. Kepuasan seksualpun diwacanakan, perempuan yang berkulit putih, termasuk kulit disekitar vaginanya, dan vagina yang rapat atau kesat, lebih menarik dan memiliki kepuasan yang ideal bagi laki-laki untuk berhubungan seksual dengan perempuan atau istri yang memiliki kriteria itu.

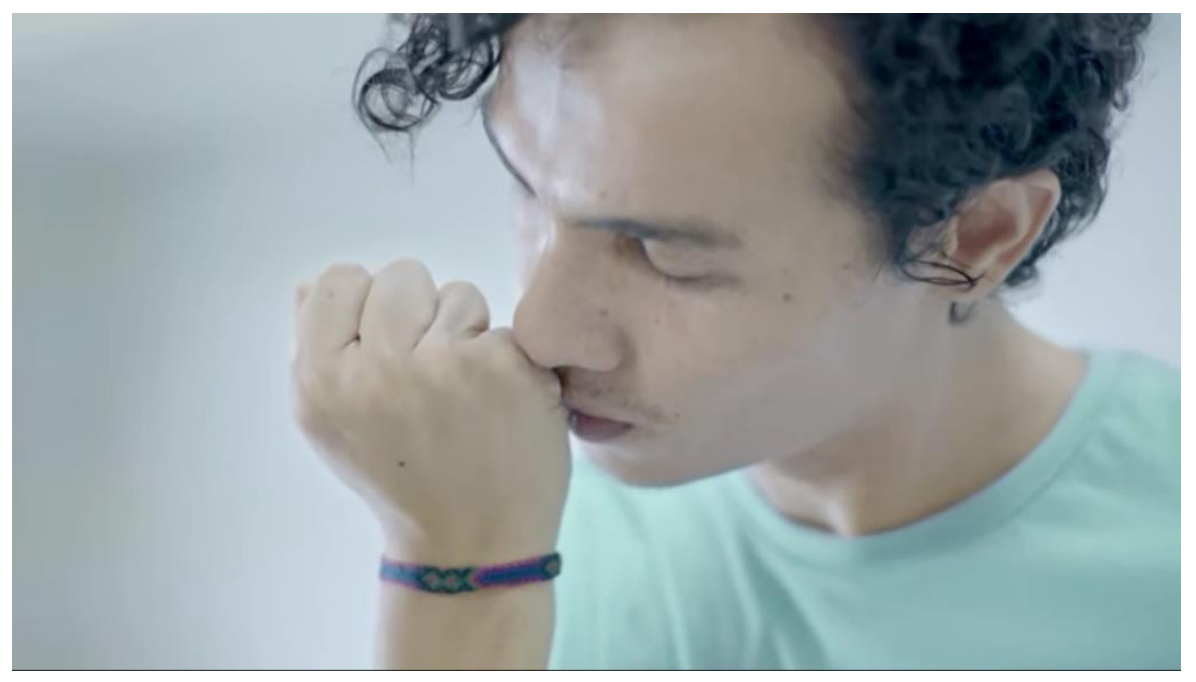

\section{Gambar 9. Komentar laki-laki ketiga}

Scene ini menunjukan laki-laki yang merujuk pada seorang suami dari perempuan pada scene ketiga. Ini juga merupakan penegasan dari scene ketiga namun dari ucapan lakilaki. Sama dengan lainnya, gerakan mengepal jari merujuk pada kerapatan, dan mendekatkan jari-jarinya ke hidung merujuk pada aroma yang wangi. Itu diperkuat dengan kata "wanginya bikin kangen" yang merujuk pada vagina istri yang wangi. Dalam tingkat konotasi, 
keberhasilan istri untuk membuat vaginanya rapat dan wangi merupakan keberhasilannya juga untuk memuaskan suami dalam hubungan seksual. Dalam hal ini istri yang ideal adalah istri yang memiliki vagina yang rapat dan beraroma wangi (Tabel 7).

Tabel 7. Analisis Gambar 9

\begin{tabular}{|l|l|}
\hline $\begin{array}{l}\text { 1. Penanda } \\
\text { Gambar laki-laki mengepal jari dan mendekatkan } \\
\text { kehidung. } \\
\text { Penanda suara "wanginya bikin kangen" }\end{array}$ & $\begin{array}{l}\text { 2. Petanda } \\
\text { Laki-laki merujuk pada seorang suami. } \\
\text { Gerakan jari mengepal diasosiasikan dengan } \\
\text { vagina yang rapat dan kata wangi juga } \\
\text { merujuk pada aroma vagina sang istri. }\end{array}$ \\
\hline $\begin{array}{l}\text { 3. Tanda / I. PENANDA: Seorang suami yang selalu merindukan istrinya karena sang istri } \\
\text { memiliki vagina yang rapat dan wangi. }\end{array}$ \\
\hline $\begin{array}{l}\text { II. PETANDA: Kepuasan seksual suami didasarkan oleh kerapatan vagina dan aroma wangi dari } \\
\text { vagina sang istri. }\end{array}$ \\
\hline III. MITOS : Istri ideal bagi suami adalah istri yang memiliki vagina rapat dan beraroma wangi \\
\hline
\end{tabular}

\section{Mitos Vagina Ideal}

Hasil analisis di atas menunjukan iklan Purbasari Manjakani Whitening memperkuat wacana dengan mitos bahwa vagina ideal adalah vagina yang kencang atau rapat, berwarna putih, dan beraroma wangi. Lebih jauh lagi, iklan tersebut menunjukan bahwa istri yang ideal adalah istri yang memiliki vagina rapat, berwarna putih, dan beraroma wangi. Tiga mitos tersebut merujuk pada satu mitos yaitu, vagina yang diidealkan memuaskan suami dalam berhubungan seksual suami istri dan memiliki dampak lanjutan yaitu terbentuk keluarga yang harmonis. Kepalan tangan dengan perlahan dan kuat menyampaikan pesan rapat atau menggigit dan keintiman. Hal itu tidak terlepas dari kepuasan seksual laki-laki, yang dalam hal ini kepuasan laki-laki dalam hubungan seksual adalah yang utama.

Bila dilihat secara keseluruhan iklan, tiga perempuan yang berkomentar itu merujuk pada istri dari 3 laki-laki yang berkomentar setelahnya. Dalam hal ini, terlihat berbagai latar belakang perempuan dan laki-laki menempatkan hubungan seksual dikonstruksikan sebagai hal yang vital dalam keharmonisan keluarga. Dengan kata lain, setiap perempuan memiliki tuntutan untuk memuaskan laki-laki dalam aspek hubungan seksual. Laki-laki mengidealkan kriteria vagina tertentu untuk mendapatkan pengalaman seksual yang memuaskan. Tiga perempuan dalam iklan itu melakukan gerak tubuh yang mendekati menurunkan kelopak mata sambil sedikit mengangkat alis, dan sedikit membuka bibir. Kelompok gerakan tersebut telah digunakan perempuan selama berabad-abad untuk menunjukan bahwa mereka mengalah dalam konteks seksual. Gerak tersebut merujuk pada ekspresi perempuan sebelum orgasme (Allan \& Pease, 2018, p. 202). Secara sederhana, perempuan diposisikan sebagai objek seksual dari laki-laki.

Mitos tidak terlepas dari penyajian wacana yang didalamnya terdapat landasan historis (Barthes, 2018, p. 153). Vagina merupakan bagian tubuh dari perempuan yang merupakan bagian vital dalam hubungan seksual. Dalam etnik Jawa di Indonesia, terdapat 
ungkapan-ungkapan yang menjadi tradisi kepercayaan terkait peran laki-laki dan perempuan. Ungkapan "konco wingking"dan "yen awan dadi theklek, lha yen bengi dadi lelek" (Kasiyan, 2008, pp. 109-113). Dalam bahasa, ungkapan itu tersebut diterjemahkan sebagai teman belakang dan perempuan itu di siang hari menjadi alas kaki (bagi laki-laki), dan di malam hari menjadi alas tidur. Hal itu merujuk pada perempuan yang diposisikan sebagai objek seks. Perempuan yang ideal dalam tradisi Jawa identik dengan tuntunan yang kompleks dengan atribut yang dipercaya meningkatkan daya tarik seksual untuk memuaskan laki-laki. Pada mitologi lain, Kendedes sebagai keturunan dewa diceritakan memiliki vagina yang bisa memancarkan cahaya. Secara sederhana, penghargaan perempuan Jawa pada saat itu fokus pada tubuh dan organ seksualnya.

Publik secara sengaja maupun tidak sengaja berkesempatan berhadapan dengan iklan yang didasarkan atas psiko-analisis (Barthes, 2018, p. 41). Pernyataan "Purbasari Manjakani Whitening, makin manja" dalam iklannya mendasarkan kehebatannya pada bukti yang dihasilkan. Iklan tersebut menanamkan rasa bangga dalam diri seseorang dalam persoalan privat yang menjadi persoalan sosial. Untuk perempuan, bangga dan lebih percaya diri untuk berhubungan seksual karena menggunakan produk Purbasari Manjakani Whitening. Untuk laki-laki, bangga karena memiliki istri dengan vagina yang diidealkan dengan menyamarkan bantuan dari produk yang berbahan kimia buatan. Iklan tersebut secara tidak langsung menyuguhkan perbandingan sebelum dan sesudah dengan menggunakan pernyataan "sejak pakai Purbasar Manjakani Whitening". Dalam hal ini, sebelum istri yang berjenis kelamin perempuan menggunakan produk tersebut, keharmonisan keluarga tidak maksimal karena hubungan seksual yang dianggap kurang memuaskan. Lebih jauh lagi, hubungan seksual dianggap kurang memuaskan karena vagina dari sang istri yang tidak putih, wangi, dan rapat atau kesat.

\section{Mitos Kerapatan Vagina Ideal}

Vagina yang rapat sebagai vagina yang ideal tidak terlepas dari nilai sosial budaya yang mengagungkan keperawanan perempuan. Dalam hal ini, perawan diidentikan dengan vagina yang masih memiliki selaput dara dan mitos vagina yang masih rapat karena belum pernah ada benda yang masuk kedalamnya. Hubungan seksual pertama kali bagi perempuan bisa terasa kurang nyaman karena masih merasa tegang dan rapat. Hal tersebut yang membuat vagina terasa rapat karena tidak terlubrikasi dengan maksimal (Baswardono, 2005, p. 82). Penetrasi seksual pada vagina dengan kondisi tersebut membuat laki-laki dikonstruksikan mendapat kepuasan seksual yang lebih dibanding dengan vagina yang menjauh dari konsep keperawanan. Keperawanan merepresentasikan hal besar dari misteri feminin. Perempuan menjadi aspek yang mengelisahkan sekaligus mempesona (Beauvoir, 2016, p. 218). Iklan Purbasari Manjakani Whitening mengkonstruksi pesan yang mendukung konsep vagina ideal yang merujuk pada keperawanan. Lebih jauh lagi, iklan ini menawarkan pengalaman berhubungan seksual dengan perawan bagi suami setelah istrinya menggunakan Purbasari Manjakani Whitening.

Hasil penelitian dari Simeon (2018, p. 7) menjelaskan vagina yang rapat juga diartikan oleh audiens sebagai vagina yang memiliki lubang kecil, kesat, tidak ada cairan yang membuatnya lembab, dan sempit atau sulit untuk dimasuki oleh penis. Ini menunjukan mitos dari produk sejenis yang saling menguatkan berhasil membentuk wacana yang 
dijadikan suatu kebenaran atau norma dominan terkait keidealan vagina. Alih-alih membuat tayangan berupa iklan yang edukatif, iklan sabun vagina justru memperkuat wacana pendisiplinan tubuh perempuan. Bila melihat ke belakang, fenomena ini tidak jauh berbeda dengan fenomena yang diteliti oleh Braun dan Kitzinger sekitar 20 tahun yang lalu. Braun dan Kitzinger (2001) melihat bahwa perempuan di Barat cenderung menginginkan vagina yang ketat namun tidak terlalu ketat, dan vagina yang longgar sebagai hal yang tidak diinginkan. Konstruksi ukuran vagina itu bermasalah karena berpotensi menciptakan situs lain yang menjadi perhatian tubuh bagi wanita, serta digunakan untuk mengontrol dan melecehkan wanita.

\section{Mitos Warna Kulit Sekitar Vagina yang Ideal}

Warna kulit di sekitar vagina yang putih juga masih terkait dengan konsep keperawanan. Putih diasosiasikan sebagai hal yang murni ataupun suci. Tuntutan kesempurnaan yang diberlakukan pada perempuan adalah latar berlakangnya yang diukur dari kemurnian vagina dari sang istri (Beauvoir, 2016, p. 221). Keperawanan merupakan rahasia paling menarik bagi laki-laki. Nilai yang dianggap sebagai kesucian itu membangkitkan harapan akan berbagai hal tersembunyi dalam aktivitas seksual bagi lakilaki (Beauvoir, 2016, p. 277). Warna putih dalam iklan juga diasosiasikan dengan kebersihan (Monica \& Luzar, 2011, p. 1092). Iklan Purbasari manjakani Whitening mengkonstruksi pesan bahwa vagina yang bersih dan ideal adalah vagina yang berwarna putih. Di sisi lain, warna kulit individu berbeda-beda.

Penelitian Simeon (2018, pp. 6-7) menemukan bahwa audiens memaknai vagina yang berwarna putih sebagai vagina yang berkulit putih, cerah, dan merata. Mitos dari iklan produk sejenispun masih mendominasi wacana dominan di masyarakat terkait kulit putih, termasuk kulit yang berada di sekitar vagina. Kulit vagina yang putih juga dilihat sebagai salah satu penilaian kebersihan bagian tubuh tersebut. Riset dari Jenkins dan O'Doherty (2020, p. 7) menunjukan bahwa berdasarkan nilai dominan, vagina yang dianggap bersih dianggap lebih menggairahkan. Lebih jauh lagi, riset Jenkins menunjukan bahwa ketika terjadi kondisi dilematis untuk memilih vagina yang sehat atau vagina yang tampak bersih, perempuan lebih memilih vagina yang tampak bersih. Prioritas vagina bersih yang ideal ini terkait dengan tekanan masyarakat untuk mencapai standar kebersihan vagina yang tidak realistis. Mitos keidealan.

\section{Mitos Wangi Vagina}

Bau vagina merupakan hal yang sering disinggung, tidak hanya dalam pembicaraan laki-laki, namun juga pembicaraan perempuan (Arivia, 2006, p. 54). Bau vagina menjadi kecemasan tersendiri bagi perempuan. Sejalan dengan penelitian Vandenburg dan Braun (Jenkins \& O’Doherty, 2020, p. 11), bau dikaitkan dengan kotoran. Delvin dkk (dalam Braun \& Sue Wilkinson, 2001, p. 22) banyak perempuan dibesarkan dengan lingkungannya untuk percaya bahwa vagina itu kotor. Robert (dalam Braun \& Sue Wilkinson, 2001, p. 22) mengidentifikasi pesan turun temurun bahwa vagina itu kotor merupakan suatu hubungan historis antara vagina dan kotoran yang membawa penyakit. Sama seperti penis, secara anatomi biologis vagina terletak dibagian tertutup hampir sepanjang hari membuat aroma wangi alami dari vagina seperti hanya imajinasi. Iklan Purbasari Manjakani Whitening berusaha untuk memberikan pesan bahwa imajinasi vagina yang wangi itu bisa terwujud 
dengan menggunakan produknya. Penekanan iklan terletak di aroma yang wangi, bukan menekankan vagina yang bersih. Iklan itu mendorong istri untuk memiliki vagina yang wangi dengan harapan agar disukai suami. Dari pesan tersebut, terbangunlah konstruksi terkait mitos vagina ideal yang wangi.

\section{Pendisiplinan Vagina Perempuan}

Mitos berkembang menjadi pendisiplinan tubuh termasuk vagina bagi perempuan, terutama perempuan yang menyandang status istri dalam konteks iklan Purbasari Manjakani Whitening. Vagina perempuan yang merupakan bagian dari tubuh perempuan dianggap perlu suatu perbaikan untuk memenuhi keatraktifan seksual dalam budaya patriarki. Lebih jauh lagi, tubuh perempuan didisiplinkan untuk memenuhi kepuasan publik (Choi, 2000, p. 67). Tujuan pendisiplinan vagina perempuan adalah menciptakan normalisasi ataupun sesuatu yang dipertahankan sebagai sesuatu yang ideal (Markula \& Pringle, 2007, p. 71). Hal itu juga merujuk pada kekuasaan yang mengatur kriteria vagina yang ideal, yaitu rapat, putih, dan rapat. Konstruksi kebenaran tentang vagina ideal membuat efek panoptik pada perempuan dan memposisikan perempuan bisa terjebak dalam pendisiplinan tubuh tanpa akhir yang merujuk pada persaingan semu. Foucault (dalam Bresler, 2013, p. 62) menilai, kondisi tersebut menjadi permainan tak berkesudahan yang tidak bisa dimenangkan.

Purbasari manjakani Whitening mendisiplinkan vagina perempuan yang mengacu pada hubungan seksual suami istri. Vagina perempuan didisiplinkan menuju pada vagina yang rapat, putih dan wangi untuk kepuasan suami. Sang istri juga merasa lebih bangga menunjukan vagina yang dianggapnya ideal pada suaminya. Hal tersebut tidak terlepas dari relasi kuasa yang mana hubungan seksual tidak lagi merupakan kepuasan kedua belah pihak, melainkan kuasa mengalir pada laki-laki sebagai suami. Dengan memuaskan suami, keluarga menjadi harmonis. Hal itu serupa dengan hasil penelitian Rosida dan Sari (2017) yang menunjukan bahwa iklan sabun vagina melegitimasi ideologi patriarki. Melalui hal tersebut konsep biopower bekerja melalui isu keharmonisan keluarga. Di sisi lain, biopower merupakan dorongan utama dalam budaya konsumen. Secara sederhana, terdapat konstruksi kebenaran yang dibuat demi kepentingan industri terhadap tubuh.

Frye dan Burner (2012, p. 72) dalam bukunya yang membahas tentang retorika makanan dalam hubungan kuasa menyatakan terdapat narasi persuasif pada teks media yang membuat masyarakat membeli produk tertentu. Hal tersebut sama dengan yang dilakukan Purbasari Manjakani Whitening melalui iklannya. Terdapat narasi bujukan lewat teks media untuk melakukan pembelian terhadap suatu produk untuk memenuhi tuntutan keidealan dari hal yang diwacanakan. Kekuasaan ataupun pengetahuan yang dianggap sebagai kebenaran bisa relevan selama kekuasaan tersebut dihubungkan dengan kebenaran lain yang hal-hal ilmiah, medias, ataupun budaya (Foucault dalam Markula \& Pringle, 2007, p. 60). Dalam hal ini iklan Purbasari Manjakani Whitening menghubungkan perempuan dengan mitos budaya.

Pendisiplinan tubuh tidak terlepas dari relasi kuasa. Kekuasaan ada di mana-mana, bukan karena itu mencakup segalanya, tetapi karena kekuasaan datang dari manapun. Wacana kebenaran dihasilakan dari satu titik pengetahuan atau kebenaran kepada titik lainnya (Foucault, 1978, p. 93). Biopower mendorong terbentuknya kategori tubuh dalam industri, teks media, dan juga masyarakat. Kategori tersebut adalah tubuh yang patuh dan tubuh yang terkutuk, termasuk vagina (Afiati, 2019, p. 171). Vagina yang patuh adalah 
vagina yang rapat, putih, dan wangi. Keidealan tersebut membentuk histerisasi tubuh perempuan karena efek panoptik tentang vagina. Histerisasi itu berkaitan dengan vagina dalam kategori terkutuk, yaitu vagina yang kendur, tampak tidak putih, dan bau yang memjadi momok bagi perempuan terutama yang berstatus sebagai istri.

\section{PENUTUP}

Penelitian ini berkesimpulan bahwa terdapat tiga mitos vagina ideal dalam iklan Purbasari Manjakani Whitening, yaitu vagina yang rapat atau kesat, kulit di sekitar vagina yang putih, dan vagina yang wangi. Lebih jauh lagi, iklan tersebut menunjukan bahwa istri yang ideal adalah istri yang memiliki vagina rapat, memiliki kulit putih termasuk disekitar vaginanya, dan beraroma wangi. Tiga mitos tersebut merujuk pada satu mitos yaitu, vagina yang diidealkan membuat suami bergairah untuk berhubungan seksual dengan istri dan memiliki dampak lanjutan yaitu terbentuk keluarga yang harmonis. Bagi perempuan atau sang istri, memiliki vagina rapat, berkulit putih, dan wangi merupakan suatu kebanggaan dan sebagai instrumen yang membuat lebih percaya diri saat berhubungan seksual dengan suami untuk memuaskan suami dalam hubungan seksual. Sedangkan bagi laki-laki atau sang suami, kebanggaan berasal dari kepemilikan istri yang memiliki vagina rapat, berkulit putih merata termasuk sekitar vagina, dan vagina yang wangi, sehingga kepuasan dalam berhubungan seksualpun bisa terpenuhi. Mitos tersebut tidak terlepas dari tradisi budaya Jawa di Indonesia melalui ungkapan maupun naskah yang menempatkan perempuan sebagai pelayan bagi laki-laki, termasuk dalam hubungan seksual. Selain itu, konsep keperawanan juga berperan dalam mitos vagina ideal yang direlevansikan dengan keharmonisan keluarga.

Mitos vagina ideal sejalan dengan pendisiplinan tubuh perempuan yang berstatus istri pada khususnya. Mitos dimaknai sebagai kebenaran sehingga membangun efek panoptik bagi perempuan untuk menjaga vaginanya dalam kategori tubuh yang patuh. Kondisi tersebut bisa membuat perempuan terjebak dalam perjalanan keidealan tanpa akhir untuk memenuhi tuntutan vagina yang ideal. Hal itu juga membuat histerisasi perempuan terkait vagina yang kendur, tampak tidak putih, dan juga bau. Konstruksi vagina ideal tidak terlepas dari relasi kuasa yang mana hubungan seksual tidak lagi merupakan kepuasan kedua belah pihak, melainkan kuasa mengalir pada laki-laki sebagai suami. Dengan memuaskan suami secara seksual, keluarga dinarasikan menjadi harmonis. Melalui hal tersebut, konsep biopower bekerja melalui isu keharmonisan keluarga. Di balik itu, terdapat konstruksi kebenaran melalui teks media untuk kepentingan industri terhadap tubuh perempuan.

Penelitian ini menyarankan agar produk sabun kewanitaan kembali beriklan di televisi dengan konsep yang lebih melihat perempuan sebagai manusia secara utuh, bukan hanya dalam konteks hubungan seksual. Industri sabun kewanitaan juga bisa memaksimalkan promosinya melalui media sosial dengan membangun konten yang edukatif. Hal itu mengingat edukasi terkait vagina di media arus utama masih minim. Konten edukatif tentang vagina memungkinkan industri mengajak audiens khususnya perempuan untuk mengenali lebih jauh terkait alat kelaminnya termasuk kesehatan maupun pemahaman tentang keberagaman vagina dari tiap perempuan. Dari situ, industri sabun kewanitaan bisa menyisipkan kegunaan dan aturan pakai dari produk yang ditawarkan. Dengan cara itu, diharapkan publik bisa memahami lebih jauh tentang vaginanya tanpa menggeneralisasi keidealan dan menggunakan produk sabun kewanitaan dengan bijak. 


\section{REFERENSI}

Adiyanto, W. (2018). Narasi Komunikasi Pengakuan Diri Perempuan Kepada Pasangannya Mengenai Ketidak Perawanan. Universitas Diponegoro.

Afiati, A. I. (2019). Mekanisme Pendisiplinan Tubuh Laki-Laki dan Perempuan Melalui Wacana Fitness di Situs Reps ID. Universitas Diponegoro.

Allan, \& Pease, B. (2018). Kitab Bahasa Tubuh. Jakarta: Gramedia Pustaka Utama.

Arivia, G. (2006). Feminisme : Sebuah Kata Hati. Jakarta: Kompas Media Nusantara.

Barthes, R. (2007). Membedah Mitos-itos Budaya Massa. Yogyakarta: Jalasutra.

Barthes, R. (2017). Elemen-Elemen Semiologi (E. A. Iyubenu, Ed.). Yogyakarta: Basa- Basi.

Barthes, R. (2018). Mitologi (Nurhadi, Ed.). Yogyakarta: Kreasi Wacana.

Baswardono, D. (2005). Perawan Tiga Detik. Yogyakarta: Galang Press.

Beauvoir, S. De. (2016). Second Sex: Fakta dan Mitos. Yogyakarta: Narasi Pustaka Promethea.

Belch, G. E., \& Michael E. Belch. (2017). Advertising and Promotion: An Integrated marketing Communication Perspective (11th ed.). New York: Mc-Graw Hill.

Bourdieu, P. (2010). Dominasi Maskulin. Yogyakarta: Jalasutra.

Bourdieu, P. (2020). Bahasa dan Kekuasaan Simbolik (Muhammad Ali Fakih, Ed.). Yogyakarta: IRCiSoD.

Braun, V., \& Kitzinger, C. (2001). The Perfectible Vagina: Size Matters. Culture, Health, and Sexuality, 3(3), 263-277.

Braun, V., \& Sue Wilkinson. (2001). Socio-Cultural Representations of the Vagina. Journal of Reproductive and Infant Pscyhhology, 19(1), 17-32.

Bresler, L. (2013). Knowing Bodies, Moving Minds: Towards Embodied Teaching and Learning. University Illinois Press.

Choi, P. Y. . (2000). Femininity and the Phisically Active Woman. London: Routledge.

CNN Indonesia. (2019). 4 Hal Bikin Wanita Tak Pede saat Berhubungan Intim. Retrieved March 29, 2021, from Cnnindonesia.com website: https://www.cnnindonesia.com/gayahidup/20190909154140-255-428806/4-hal-bikin-wanita-tak-pede-saat-berhubunganintim

Denzin, N. K., \& Lincoln, Y. S. (2009). Handbook of Qualitative Research. Yogyakarta: Pustaka Pelajar.

Dewi, B. K. (2016). Waspadai Efek Samping Sabun Pembersih Vagina. Retrieved March 3, 2021, from Kompas.com website: https://lifestyle.kompas.com/read/2016/01/10/192000623/wapadai.efek.samping.sabun. pembersih.vagina?page $=$ all

Foucault, M. (1978). The History of Sexuality Volume 1: An Introduction. New York: Pantheon Books.

Frye, \& Bruner. (2012). The Rhetoric of Food: Discourse, Materiality, and Power. New York: Routledge.

Haryatmoko. (2007). Etika Komunikasi Manipulasi Media, Kekerasan dan Pornografi. Yogjakarta: Kanisius.

Jenkins, A., \& O'Doherty, K. C. (2020). The Clean Vagina, The Healthy Vagina, and The Dirty Vagina: Exploring Women's Portrayals of The Vagina in Relation to Vaginal Cleansing Product Use. Feminism and Psychology, O(0), 1-20. https://doi.org/10.1177/0959353520944144

Kania, D. (2019). Perawatan Ini Bikin Lubang Miss V Lebih 'Menggigit, Dijamin Suami Makin Sayang. Retrieved March 29, 2021, from okezone.com website: https://lifestyle.okezone.com/read/2019/03/06/485/2026557/perawatan-ini-bikinlubang-miss-v-lebih-menggigit-dijamin-suami-makin-sayang\# 
Kasiyan. (2008). Manipulasi dan Dehumanisasi Perempuan dalam Iklan. Yogyakarta: Ombak.

Markula, P., \& Pringle, R. (2007). Foucault, Sport \& Exercise. London: Routledge.

Monica, \& Luzar, L. C. (2011). Efek Warna Dalam Dunia Desain dan Periklanan. Humaniora, 2(2), 1084-1098.

Phillips, M. J. (1997). Ethics and Manipulation in Advertising: Answering a Flawed Indictment. London: Quorum Books.

Primastika, W. (2018). Amankah Produk Pembersih Khusus Area Vagina? Retrieved March 6, 2021, from Tirto.id website: https://tirto.id/amankah-produk-pembersih-khusus-areavagina-cVmK

Purnamasari, N. I. (2020). Audience reception Related to Freedom of Life Partner in Aladdin Film. Jurnal ISKI, 5(1), 31-41.

Radford, G. P. (2005). On The Philosophy of Communication. Wadsworth: Thomson.

Risman, I. S., \& Karim. (2020). Citra Perempuan dalam Iklan Sabun Shinzui. Sang Pencerah, 6(1), 2020.

Rodrigues, S. (2012). From Vaginal Exception to Exceptional Vagina: The Biopolitics of Female Genital Cosmetic Surgery. Sexualities, 15(7), 778-794.

Rosida, I., \& Sari, S. W. (2017). The Representation of Islam Identity on the Commercial TV's Advertisements. International Conference on Culture and Language in Southeast Asia (ICCLAS 2017), 129-131. Jakarta: Atlantis Press.

Simeon, N. P. B. (2018). Pemaknaan Khalayak Terhadap Konstruksi Vagina dalam Iklan Produk Feminine Hygiene Resik V. Jurnal Interaksi, 6(1).

Sobur, A. (2016). Semiotika Komunikasi. Bandung: Remaja Rosdakarya.

Sukmasari, R. N. (2017). Ini Soal Kekhawatiran Jadi "Kendur" Setelah Melahirkan. Retrieved March 29, 2021, from Hai Bunda website: https://www.haibunda.com/kehamilan/20170820090302-49-6957/ini-soalkekhawatiran-jadi-kendur-setelah-melahirkan

Sunarto. (2009). Televisi, Kekerasan, dan Perempuan. Jakarta: Kompas Media Nusantara.

Tharps, L. L. (2016). The Difference Between Racism and Colorism. Retrieved June 29, 2021, from Time.com website: https://time.com/4512430/colorism-in-america/

Top Brand Awards. (2020). Top Brand Index. Jakarta. Retrieved from https://www.topbrand-award.com/top-brand-index/?tbi_find=purbasari

Virdhani, M. H. (2019). Ketahui 5 Penyebab Miss V Kendur dan Dikeluhkan Suami. Retrieved March 29, 2021, from Jawapos.com website: https://www.jawapos.com/kesehatan/health-issues/08/03/2019/ketahui-5-penyebabmiss-v-kendur-dan-dikeluhkan-suami/ 